\title{
Maritime Potential Phenomenon in Improving the Welfare of the Riau Island Community
}

\author{
Yuanita FD Sidabutar ${ }^{1 *}$, Edi Indra ${ }^{2}$ \\ ${ }^{1}$ Programme Director Master's Program in Regional Planning Batam University, Indonesia \\ ${ }^{2}$ Dean of Engineering Faculty Batam University, Indonesia \\ Email: yuanita.fd@univbatam.ac.id,edi.indra@univbatam.ac.id
}

\begin{abstract}
The geographical potential of the Riau Island has an area of 251,610 sq km and 96 percent of which is the ocean and only 4 percent of the land. Since the formation of the Riau Islands Province in 2002, the wealth of marine resources has not received widespread, serious, and serious attention. At the same time, the Riau Islands Province has a very large marine wealth. This causes the Riau Islands to have the potential and competitiveness of wealth in the seas. The people of the Riau Islands must be aware of potential planning and problems and recognize plans for improvement for the benefit of the community. Therefore, a plan that is logical, realistic, implementable, flexible, and acceptable to society. The hierarchy of potential space is formed based on the functions that surround it. The purpose of this research is to reveal the hierarchy, public awareness, maritime potential in the marine area that can be worked on in the use of marine space, fisheries, mining, and tourism. This research is descriptive-analytical and based on theoretical and empirical elaboration. This approach is to examine the maritime potential space of the Riau Islands to get a reference for the interpretation of theoretical relationships from an empirical condition.
\end{abstract}

\section{Introduction}

An area has specific conditions, with the characteristics of a specific coastal area an aggregation of various ecological and physical components that influence each other, and are ecologically very fragile. Development or exploitation of natural resources that does not pay attention to ecological principles will very easily damage the process or function of the coastal ecosystem. In addition, it is shown that there are communities and the presence of multiple activities in coastal areas, for example: farmers, fishermen, farmers, industrial entrepreneurs, hotels and tourism recreation, and businesses related to the sea or the coast.

In regional development planning, a regional delineation is often carried out in which there are activities to determine regional boundaries. Determination of regional boundaries by taking into account the concept of territory. In this regard, the concept of territory emphasizes "region" as a means (means) for a goal rather than its own purpose. As a concept, it can be demonstrated by taking the example of the area concept that has been used as a classification method through two different phases, namely from a phase that reflects economic progress from a simple agrarian economy to a complex industrial system.

Riau Islands Province has a very strategic geographical location in international trade traffic routes. The government seizes the opportunity by taking advantage of the strategic location of the three islands (Batam, Bintan and Karimun). In addition, the three islands can be used as gateways for the inflow of investment in goods and services abroad, and can function as a center for the development of technologyladen industries. KPBPB can also function as a place for collecting and distributing production products from and to all regions of Indonesia and other countries, as well as being a center for international ship traffic services.

Since the formation of the Riau Islands Province in 2002 , the wealth of marine resources has not received widespread, serious and serious attention. This is because the government still considers the mainland as the prima donna in developing economic potential for the realization of community welfare. Whereas the Riau Islands Province has a very large marine wealth.

Many people think that talking about maritime is only limited to shipping and trade without seeing its greatest potential, namely the sustainability of the marine ecosystem and the life of the maritime space.

Maritime potential space has a formal area, namely a geographical area that has an ecosystem (ecological and biological components as well as the physical environment) and their interactions. Ecological and biological components include animals, plants and organisms. The interaction between components of the ecosystem through the exchange of energy and substances, starting with the conservation of sunlight, basic nutrients, carbon dioxide and minerals by plants (primary producers) into plant tissues which are the basic ingredients of food for animals. All of this is a maritime space that strongly supports natural resource

\footnotetext{
* Corresponding Author: yuanita.fd@univbatam.ac.id
} 
management activities in creating the regional economy for the welfare of the community.

\section{Research methods}

This research is descriptive-analytical and based on theoretical and empirical elaboration. This approach is used to read maritime space in the Riau Islands to get a reference for the interpretation of theoretical relationships from an empirical condition.

\section{Results and Discussion}

The word potential is an ability that has the possibility to developed, both in terms of strength and ability and power. Maritime is matters related to maritime affairs, shipping and trade in the sea which is archipelagic.

The maritime potential of the Riau Island is everything contained in the waters of the Riau Island and can be utilized for the welfare and interests of the people of the Riau Island. Maritime potential routes in terms of Batam's National and International shipping (figure 1)

\section{Figure 1. Batam National and International Shipping}

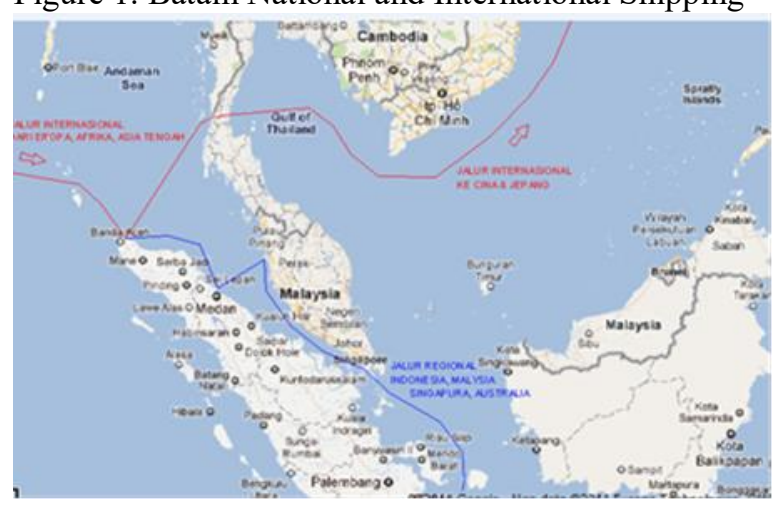

Lines

This potential phenomenon is contained in the form of public space that can be understood and intended from human experience to explain human situations, events and experiences as something that arises and is present in togetherness (Von Eckartsberg, 1980).

Regional planning and development is expected to produce maritime potential spatial planning with maritime allocations in accordance with its designation, such as maritime/marine potential areas, shipping and trade in the sea which are archipelagic. So that maritime potential space activities go hand in hand with economic development, especially with the implementation of Batam as a Free Trade Area and Free Port, it is necessary to build a modern infrastructure network that is more economic in a limited area. Rodrik (2001: 5-6) reveals that the use of geographic location will affect economic growth through two factors. First, the use of geographic location will affect a country to be able to integrate with the global market, regardless of the policies of the country concerned. Furthermore, the distance and isolated conditions will further increase the cost of integration. Second, geographical conditions will affect the side of institutional development, especially through the colonization route from historical experience built from geopolitical situations and natural resources through the existence of rent seeking behavior and rent distribution institutions.

Johansson and Nilsson (1997: 2115), a special economic zone is an area which geographically and legally is an area where free trade, including facilities and duty free facilities for the importation of capital goods for raw materials for export commodities, is opened as wide as possible.

Each province with an archipelagic character has the authority to manage marine resources in its territory. However, the characteristics in the northern, central and eastern parts of Indonesia are different. The northern region of Indonesia, namely the Riau Island Province, is a province characterized by islands which are directly adjacent to several neighboring countries such as Singapore, Malaysia, and Vietnam and this area is a route for tradeinternational and also the Silk Road. Therefore, the northern regions of Indonesia are accustomed to trade and shipping.

Riau Islands Province consists of 7 regencies/cities, 70 sub-districts and 416 Village. The total population of this province until 2017 amounted to 2,082,694 people. The distribution of the population of the Riau Islands Province is very uneven between districts/cities. Most of the population of the Riau Islands Province live in Batam City, which is 60.96 percent in 2016

Meanwhile, in Natuna, Lingga, and Anambas Islands only 3.71 percent, 4.39 percent, and 2.02 percent with uneven population distribution, Riau Islands Province is the 32 nd province formed based on Law Number 25 of 2002 on September 24, 2002. In de jure Riau Islands Province has reached the age of 16 (sixteen) years, but de facto operational implementation

Considering that the Riau Islands Province is a coastal area and small islands, development in the Riau Islands Province will adjust to the conditions and characteristics of the area. The marine potential in the Riau Islands Province includes: capture fisheries production and aquaculture, anchoring, ship to ship, ship lay-up, marine tourism, marine mineral potential, etc. Meanwhile, the Lampa Strait (Natuna) is one of the central pilot projects as the center of an integrated fisheries area. In addition, the characteristics of the Riau Islands Province geographically have a wider ocean area than the mainland area in which there are islands that form a group of islands so that they become a geographical and social unit.

Therefore, marine development is an absolute thing that must be done by the Riau Islands Provincial government. There are efforts by the Riau Province government to carry out marine development, such efforts can be seen in the existence of the Riau Islands Province Marine and Fisheries Service. 
Figure 2 The Life of the Coastal Community of the Riau Island
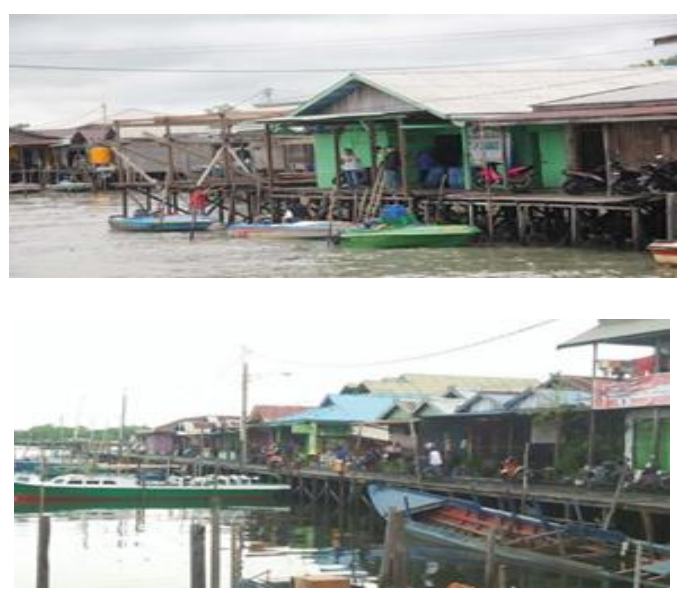

This maritime potential phenomenon has several things described as follows:

a. The phenomenon of marine development in the Riau Islands province is still prioritizing development on land and making the government at sea an option. People will be carried away by this phenomenon so that they think that life with great potential is no longer visible. Even though the opportunity for that is very large and profitable. Especially in improving people's mindset in the value of welfare in managing maritime potential. The driving factor in implementing the government system in the Riau Islands Province is the imbalance between the area and the existing population will affect the lives of people in the Riau Islands Province. The existence of disparities between the populations will not be able to make the utilization of the marine sector run optimally.

b. The phenomenon of maritime potential which includes IUU fishing practices. Where several areas of Indonesian marine waters have experienced symptoms of overfishing. In addition, in the Riau Archipelago Province, IUU fishing practices occur in the Riau Islands Province

Fisheries Management 711 which is directly adjacent to neighboring countries. State losses due to IUU fishing in Arafura waters are estimated to reach Rp. 11-17 trillion.

c. The phenomenon of maritime potential in the low production of capture fisheries compared to existing potential (Estimated Potential SDI WPP 711 is $1,057,050$ tons / year compared to the utilization rate of Riau Islands fishermen which is only 407,235.91 or $38.5 \%$ in 2015). Then the low aquaculture production compared to the existing potential (potential for marine aquaculture 455,780 ha, the utilization that occurs is only

2,218 ha $(0.5 \%)$ ) while (potential for brackish water cultivation area 2,063 ha, utilization: $69.1 \mathrm{~h}$ (3.34\%)); (Potential of fresh water cultivation land $(8,111.21 \mathrm{ha})$ : utilization is only $4,427.65$ ha $(54.59 \%)$.)

d. The phenomenon of maritime potential in terms of the government system in marine development in the province, the response or response in this study is seen from the stakeholder side, namely the Riau Islands Provincial Government. The responses that emerged were;

1. Government policies related to the development of marine areas, coastal areas and small islands.

2. Establishment of FTZ (Free Trade Zone), namely the areas of Batam, Bintan, Karimun and parts of Tanjung Pinang which are free trade areas and free ports. Development of marine aquaculture for fishermen;

3. Development of marine aquaculture to the community.

e. The phenomenon of maritime potential in the availability of a dense and integrated modern infrastructure network such as roads, electricity, water, information and communication technology, ports and others, in such a way that the development process of building community welfare can take place efficiently and effectively.

The phenomenon of maritime potential cannot be separated from problems and conflicts that tend to occur due to the existence of "multiple management entities", namely fragmentation in decision making, duplication/overlapping of authority/jurisdiction is ineffective and inefficient. To be effective and efficient, the problem must be solved. Conflict sometimes has a positive impact in stimulating creative problem solving in public management. However, prolonged conflicts of authority and interests will hinder the achievement of the goal of improving the quality of the regional environment and marine ecosystems.

Maritime potential is dominated by activities that have not been maximally organized so that the achievements and targets for community welfare have not been fulfilled. People who do not live from the maritime sphere but appear in maritime life and occupy the maritime potential space. Private parties from the economic and large-scale business sectors as well as dominant government organizations that can take over the maritime potential space formally.

In fact, Riau Islands maritime is not absolutely open which can be entered by the community to carry out maritime interaction activities in it as a livelihood opportunity. As a place that has maritime potential where there are individual and group interaction activities taking place in it, there is a limit (hierarchy) for using the maritime potential space.

\section{Conclusion}

The conclusion from the above description is as follows:

1. In fact, since the maritime potential of the Riau Islands province was founded in 2002, the wealth of marine resources has not received widespread, serious and serious attention. Whereas the Riau Islands Province has a very large marine wealth.

2. In general, maritime development and potential move with the influence of maritime phenomena which no longer focus on the welfare of the 
community. The target community is a community that 100 percent of their lives are in maritime areas.

a. So that it changes the image of living on the coast or living from marine life that is poverty and backwardness.

3. Community welfare from maritime potential is not just a theory but a real application in the placement and organization of opportunities and opportunities to provide these opportunities and supported by the government.

4. The hierarchy of actors in the use of maritime potential space is prioritized on the space for people who 100 percent live on the side of marine and coastal life. Given in the process of human social civility, mobilizing the economic aspect of the marine area, capital adequacy and seizing opportunities.

5. The phenomenon of maritime potential in the past few years is a lesson and improvement in future regional planning in the Riau Islands. The gathered forces interpret the value of unity in building a maritime orientation starting from the community instilling a sense of concern, changing the mindset that maritime life opens up great opportunities in living well-being, the motivation to seize opportunities properly without violating the laws or regulations that apply.

6. Establish and seek the value of community satisfaction in obtaining welfare from the life of maritime potential.

\section{References}

1. Dick, HW and Rimmer PJ, 1997, Beyond The Third World City: The New Urban Geography Of South-East Asia. Urban Studies.

2. Ekomadyo, Agus (2009), Control Quality of City Architecture in Space Public in Pekanbaru City, Dissertation, ITB.

3. Groat, Linda and Wang, David. 2002. Architectural Research Methods. John Wiley \& Sons.

4. Gehl, Jan, 1987, Life Beetwen Building, Island Press.

5. Hantono, D., Prayitno, B., \& Pramitasari, D. (2021). Adaptation of Physical Setting to the Appearance of the Jiung Night Market at Public Open Space in Jakarta. Civil Engineering and Architecture, 9(4), 1137-1143 https://doi.org/10.13189/cea.2021.090415

6. Indera Edi, Sihombing Marlon, Chairul Muluk, Rujiman, Chablullah Wibisono 2018. "Termination of the development of free trade areas and free ports (KPBPB) for Regional Development in Batam City, Abstract ID AIMC 2018-STEM-807, International Journal of Engineering\&Technology, Website; www.sciencepubco.com/index.php/IJET

7. Krier, Rob, Urban Space, 1979, New York Press.
8. Sidabutar, Yuanita FD, Sirojuzilam, Suwardi Lubis and Rujiman, 2018. "The Influence Of Building Quality, Environmental Conditions of Historical Building and Community Participation to Cultural Tourism inMedan City." International Journal of Civil Engineering and Technology IJCIET), Volume 9, Issue 3, March 2018, pp. 259270, article ID; IJCIET_09_03_028. IAEME

9. Sidabutar, Yuanita FD, 2007. "Utilizing the Existence of Historic Buildings in Supporting Regional Development Activities of Medan City," Wahana Hijau Journal, Medan.Vol. 3 Number 1, August 2007.

10. Sulasdi, WN (2012). Integration Pattern Development of Coastal and Marine Areas. Main Material Book Material.

11. The 1945 Constitution article $33: 3$

12. Law No. 15 of 1985 about UNCLOS

13. Law 32 of 2014About Marine

14. Law No. 23 of 2014 About Local Government

15. Law No. 25 Year 2004 About Planning System National development

16. 16] Law No. 17 of 2007 About the Term Development Plan National Length 2005-2025

17. Winarno, B. (2007). Globalization and the Crisis of Democracy. MedPress.

18. Zen, MT (2001). Basic Philosophy Regional Development: Empowering People. Three Pillars Area Development. Agency for the Assessment and Application of Technology. 2nd Edition (revised). pp. 4-5. Jakarta 